University of Wollongong

Research Online

Faculty of Social Sciences - Papers (Archive) Faculty of Arts, Social Sciences \& Humanities

2015

Arriving, surviving, and succeeding: first-in-family women and their experiences of transitioning into the first year of university

Sarah Elizabeth O'Shea

University of Wollongong, sarah.oshea@curtin.edu.au

Follow this and additional works at: https://ro.uow.edu.au/sspapers

Part of the Education Commons, and the Social and Behavioral Sciences Commons

Research Online is the open access institutional repository for the University of Wollongong. For further information contact the UOW Library: research-pubs@uow.edu.au 


\title{
Arriving, surviving, and succeeding: first-in-family women and their experiences of transitioning into the first year of university
}

\author{
Abstract \\ This article outlines a qualitative narrative inquiry study conducted within Australia that focused on a \\ group of female students commencing university, all of whom were the first in their family to pursue \\ higher education. During 1 year of academic study, 17 women participated in periodic interviews as each \\ moved through the year. By following the students, the study reveals a very different perspective on the \\ student experience, one that is often missing in policy documents and university discourse, which can \\ place these students within a deficit discourse. Instead, by approaching this topic from a strengths \\ perspective, the intent was to highlight how those in this group persist and engage throughout the year. \\ The semi structured interviews built upon each other, and themes were explored related to how the \\ participants managed their university studies in relation to other competing demands in their lives, as well \\ as how the students reflected upon the transition to university life and the repercussions that this \\ decision provoked. The participants' reflections reveal an initial disjuncture with the university \\ environment, but as the year proceeded, the narratives highlight changes in personal perceptions from \\ that of exclusion to inclusion.
}

\section{Keywords}

surviving, arriving, succeeding, university, first, year, their, family, experiences, transitioning, into, women

\section{Disciplines}

Education | Social and Behavioral Sciences

\section{Publication Details}

O'Shea, S. (2015). Arriving, surviving, and succeeding: first-in-family women and their experiences of transitioning into the first year of university. Journal of College Student Development, 56 (5), 499-517. 


\title{
Arriving, Surviving, and Succeeding: First-in- Family Women and Their Experiences of Transitioning Into the First Year of University.
}

\author{
Sarah O'Shea
}

This article outlines a qualitative narrative inquiry study conducted within Australia that focused on a group of female students commencing university, all of whom were the first in their family to pursue higher education. During 1 year of academic study, 17 women participated in periodic interviews as each moved through the year. By following the students, the study reveals a very different perspective on the student experience, one that is often missing in policy documents and university discourse, which can place these students within a deficit discourse. Instead, by approaching this topic from a strengths perspective, the intent was to highlight how those in this group persist and engage throughout the year. The semi structured interviews built upon each other, and themes were explored related to how the participants managed their university studies in relation to other competing demands in their lives, as well as how the students reflected upon the transition to university life and the repercussions that this decision provoked. The participants' reflections reveal an initial disjuncture with the university environment, but as the year proceeded, the narratives highlight changes in personal perceptions from that of exclusion to inclusion.

The literature on first-year transition reveals how beginning university study often initiates feelings of fear and self-doubt for newcomers, as students acculturate to a new and somewhat alien environment. Kantanis (2000) describes how many commencing students experience a "sense of dilemma at the very least and utter confusion at worst, as to their expected role and responsibilities" (p. 106). For those individuals who have no friends or family members to provide guidance as they adapt to this university culture, these types of feelings can be elevated. Indeed, first-generation or firstin-family students are particularly vulnerable to attrition within the higher education environment; empirical evidence in Canada shows that after financial considerations, parental educational attainment is a strong predictor of academic success (Lehmann, 2009). Equally in America, the National Center for Education Statistics (Chen, 2005) indicates that first-in-family students are less likely to graduate from university when compared to those students who have at least one parent who had postsecondary qualifications. The NCES report "First-Generation Students in Postsecondary Education" indicates how $43 \%$ of first in family or first generation who entered postsecondary education between 1992 and 2000 left without a degree. While $24 \%$ of this student cohort did attain a degree during this period, this is a substantially

Sarah O'Shea is a Senior Lecturer in Social Sciences at the University of Wollongong, Australia. 
lower rate of graduation when compared to students who have parents who are university graduates $(64 \%)$.

In Australia, there is no national data set that records first-in-family status, rather the collection of this information is left to individual educational institutions. What data do exist indicate that those individuals who have one or both parents with a degree qualification were more likely to enrol in a university (Australian Bureau of Statistics, 2009), but the levels of academic success or the attrition numbers for this particular cohort are not available nationally. Overall, the literature and research that does exist in this area emphasise how the complex nature of transition and engagement may be exaggerated for those who are the first in family to come to university (Mehta, Newbold \& O'Rourke, 2011; Oldfield, 2012; Pascarella, Pierson, Wolniak, \& Terenzini, 2004; Rendon, 1995; among others).

The lack of data on this cohort within Australia and the individual nature of the university student experience both partially provided the impetus for this study. The research was also borne out of a personal desire to understand more about how first-in-family students manage this experience and succeed in this environment. Having worked in the university student support field for over 10 years, I had witnessed this cohort arrive at university with tangible gaps in knowledge particularly in relation to institutional and academic expectations; while some did depart, others managed to overcome these issues and ultimately achieve success. I sought to explore how such students individually and personally experience university in order to provide a better understanding of the personal and unique trajectory that students who are first in family may have to negotiate. In essence, the research questions guiding the overall study were: What assisted students to persist in this environment? And how did they enact success? The study was small scale but provided rich data framed by the words of the student participants themselves. The importance of foregrounding student voice is also recognised by West (1996) who states:

Learners themselves have rarely been encouraged to reflect, in a flexible and longitudinal way, on their reasons for educational participation and learning in the context of past as well as present lives. (p. 1)

I sought to address this gap by engendering deep and rich levels of narrative description, recognising that local research is "critically situated" and best positioned to "generate webs of connections" as it moves from the local to the global (Quinn, 2005, p. 61). The advantage of such qualitative small-scale studies lies precisely in this specificity, rather than an attempt at homogeneity.

The students' stories featured in this article focus on personal journeys and in so doing, contribute to a deeper understanding about not only the challenges but also the encouragements encountered as they move through the academic year. I examined how students defined the university environment and also how they integrated this activity with their life. The role of relationships in the enacting of persistence and engagement was also examined in order to explore the impact of existing and new social connections. Finally, the reflections of the students over the year as a whole, provide final insight into both how this decision was ultimately framed and how the research process itself impacted this experience.

\section{LITERATURE REVIEW}

Given the diversity of literature in the field of first-year transition, this section will focus on three key themes within the literature and explore these not only within an Australian 
context but also reference literature within the United Kingdom and the United States of America. Themes include: the increasing diversity of student populations within the global university sector; considerations around first-in-family students; and the specific issues faced by women returning to education.

\section{Global Student Diversity}

The last two decades have witnessed fundamental changes in the higher education sector, particularly in relation to demographics. Increases in the numbers of students who are mature-aged or who have accessed university through nontraditional means is a global development, but this has not necessarily negotiated a more equitable educational landscape. Schuetze and Slowey (2002) compared participation rates across 10 countries and highlight how increased numbers have not removed "unequal rates of participation by different social groups" (p. 314). Researchers in the UK, North America, and Australia have revealed similar patterns in participation rates (CouvillionLandry, 2002-2003; Forsyth \& Furlong, 2003; James, 2008).

In Australia, while little consistent data record the participation of students who are first in family to attend university, the data on students who are derived from low socioeconomic status (SES) are available. While identifying low-SES status is fraught with inconsistencies, given the census collection districts and postcode indicators currently utilised in Australia*, the figures for access and participation remain noticeably skewed towards certain populations. For example, higher participation rates of students from
low-SES backgrounds are recorded at regional universities (James, 2008) whereas in the more elite universities, participation of lowSES students continues to be recorded below the national average of $15.5 \%$. Differences in participation are also noted by the Higher Education Funding Council for England (2010), which estimates that fewer than 1 in 5 students from low-SES backgrounds enter universities compared to 1 in 2 from more advantaged or wealthier backgrounds. Similarly, the U.S. Department of Education has not only reported that students from lowSES backgrounds are underrepresented in postsecondary education, but also identifies how this cohort are more likely to attend a 2-year institution (Wyatt \& Mattern, 2011).

To address such inequity in university access, a number of countries have introduced targets for student access and participation. Participation benchmarks have been noted in Germany, Sweden, Ireland, Finland, and the United Kingdom, among others (Bradley, Noonan, Nugent, \& Scales, 2008). Most of these participation targets recognise the need to attract and engage older students as well as those who have recently left school; however, the issue of higher education participation is not simply about getting individuals to attend universities, but also about retaining them once they arrive. Non completion or student drop-out within Australia consistently exceeds $20 \%$ of the total student population, and while a recent briefing from the Australasian Survey of Student Engagement (Coates \& Ransom, 2011) indicates that the number of first-year students considering departure dropped by $7 \%$ between 2008 and 2010, the percentage who do consider leaving remains a significant $27 \%$

* Prior to 2010, socioeconomic status (SES) was measured in relation to postcodes: low, medium, and high SES status were calculated by Australian Bureau of Statistics data on factors such as income, educational attainment, employment status, and dwelling types. This measure was regarded as crude and flawed. Since 2010, this measurement has been refined by drawing on data within census collection districts, which are more narrowly comprised of 250 households in a common postcode. 
of this population. In order to successfully retain students, particularly those from diverse backgrounds, it is necessary to research the continually evolving nature of the university experience and to remain mindful of the many competing demands and considerations that impact on student experience.

\section{First-in-Family Students and Higher Education}

Pascarella et al. (2004) identify how the literature on first-generation students falls into three main categories. The first body of literature these authors categorise is largely comparative, distinguishing the characteristics of first-in-family students in relation to their peers. This literature and research seems to largely agree that this cohort is particularly disadvantaged in terms of preparedness for, and knowledge of, higher education institutions, levels of financial support, and expectations around the degree. Undoubtedly for younger students with no parental history of university attendance, both parents and students have a steep learning curve. Harrell and Forney (2003) identify how the lack of someone in the family with a higher education background limits the guidance available to this student cohort as they navigate the culture of this tertiary experience (p. 155). Thayer (2000) sums up some of the disadvantages encountered by this group as including not only lower levels of academic preparedness and less knowledge or understanding about the college experience, but also less family or peer support, further postulating that these students are less likely to encounter a welcoming environment on campus. In a similar vein, Couvillion-Landry (2002-2003) argues that for those communities and families where attending university is not the norm, the difficulties associated with acculturating to this academic world may lead to "guilt, pain and confusion" as students attempt "to live simultaneously in both worlds, while being accepted in neither" (p. 3). Rendon (1992) succinctly defines the emotions and experiences of students who are the first in the family to attend university as:

a feeling of alienation that moves the students from the concrete to abstract experience and that takes the student from an old culture that is vastly different in tradition, style and values to a new world of unfamiliar intellectual conventions, practices and assumptions. (p. 56)

These types of findings reflect the second body of literature identified by Pascarella et al. (2004), which focuses on transitional issues related to entering tertiary institutions. Again this process is noted as being more problematic for first-generation students with the authors arguing that:

Not only do first-generation students confront all the anxieties, dislocations and difficulties of any college student, their experiences often involve substantial cultural as well as academic transitions. (p. 250)

The third literature theme outlined by Pascarella et al. (2004) relates to the high attrition rates of first-in-family students and the differences in postgraduation outcomes; however, the authors identify that relatively little research exists on the actual college or university experience of students, an area that this study focuses on through in-depth qualitative interviews with the students themselves. In addition, much of the existing literature focuses on younger students who are coming straight from high school into university. I would argue that the diverse nature of the student population warrants closer attention on those students from a range of ages and demographic backgrounds.

Indeed, defining students into specific cohort groups, such as first in family, can be 
both limiting and somewhat simplistic, failing to recognise that students fall into various categories or groupings. In the literature on first-year experience the usefulness of demarcating students into discrete categories has been questioned (James, 2008; Hillman, 2005), and so this study contributes to the field by also providing an in-depth analysis of the experiences of students who fall into multiple equity categories. The participants who agreed to be involved in this study are richly diverse and include those who are first in family, who are female, some are single parents, and all are from low-SES postcodes. Each of these factors can impact upon the student experiences as the literature in this field attests, and exploring this diversity in a richly descriptive manner assists in understanding how we, as university educationalists and support staff, can better assist these types of students in their educational journeys.

\section{Women Returning to Education}

Internationally, the numbers of women attending university has increased to such an extent that in some countries women outnumber men in higher education institutions (Wakeling \& Kyriacou, 2010). The Australian Bureau of Statistics (2009) indicates that the number of females with a bachelor degree or above is currently $25 \%$ of the population, while the number of men is $21 \%$; equally, in the UK $56 \%$ of first-degree graduates in 2010/11 were women (Higher Education and Statistics Agency, 2012). In the USA, the National Centre for Educational Statistics (NCES) indicates that between 2000-2010, the number of female enrolments rose $39 \%$ compared with $35 \%$ for men (NCES, 2012). Despite an increase in the participation of women, this group frequently encounters unique educational issues compared to their male counterparts. Indeed, a diverse body of literature indicates how women, particularly those who are from low-SES backgrounds, are restricted in their choices and aspirations relating to higher education (Evans, 2009; Gorard et al., 2006; Walkerdine, Lucey, \& Melody, 2001). Wakeling and Kyriacou (2010) point out that globally the gendered nature of female educational participation is reflected in the overrepresentation of women in traditional female caregiving professions, such as health and education. Female returners and older women also experience issues within the personal domain and these can also impact on their success and persistence within the higher education sector.

Emotions such as self-doubt and anxiety are regarded as being more pronounced for older females who return to education (Reay, Crozier, \& Clayton, 2009). These authors suggest that generally women are more questioning of their ability and right to attend such institutions (pp. 117-118). In earlier research, Reay (1998) identifies how women from working class backgrounds may regard movements into the HE environment as "risky enterprises in which the loss could outweigh the gains" (p. 14). Other losses and risks relate to the more practical aspects of studying, particularly the financial repercussions this decision can have. The literature on older women with caring responsibilities returning to higher education also indicates the challenges encountered (Edwards, 1993; Reay, 1998). How older women's higher education engagement impacts upon family and caring responsibilities then warrants closer and more "nuanced" attention (Vaccaro \& Lovell, 2010, p. 163).

\section{THEORETICAL FRAMEWORK}

The theoretical framework used to inform this study is based upon the notion of cultural capital and how our understanding of this both influences and directs educational experience. 
Cultural capital is defined as "proficiency in and familiarity with dominant cultural codes and practices" (Aschaffenburg \& Maas, 1997, p. 573). Such codes and practices include those found within the educational system and in particular within HE. For those individuals who have limited exposure to this environment, this lack of knowledge can limit success, and these institutions can act in a gate-keeping capacity within the social system. As Bourdieu and Passeron (1977) highlight "academic qualifications are to cultural capital what money is to economic capital" (p. 187). Bourdieu (1977) questioned the concept of individual educational giftedness and instead pointed to class-based factors as a precursor to success in the education system. Individuals enter this system with different types of cultural capital and knowledge, which are based upon their social background; hence, educational success is not necessarily a result of natural abilities but rather relates to the "affinity between class cultural habits and the demands of the educational system or the criteria which define success within it" (Bourdieu \& Passeron, 1977, p. 22). This systematic inequality is played out throughout the education system: individuals endowed with the requisite and accepted forms of capital experiencing success; this helps to guarantee their positionality within the social order, perpetuating a class-based system.

Bourdieu's (1977) theory is not without its critics with the reproductive nature of his theorisation attracting the most critical attention. For example, the concept of habitus is proposed as a means to refer to the ways in which individuals are disposed to behave and react based on cultural affiliations and understandings. This is suggestive of a lack of individual agency and appears to limit the possibility for change and transformation. However, habitus is better defined as a "portfolio of dispositions, such as individual beliefs, values speech, dress which strongly influence actions in any situation" (Bloomer \& Hodkinson, 2000, p. 589). Similarly, concepts such as cultural capital can be criticized for their limiting nature and so this study has adopted Yosso's (2005) community cultural wealth framework that extends and challenges established conceptions of cultural capital. Yosso argues that Bourdieuian cultural capital theory is too narrow in its recognition of "assets and characteristics" (p. 77) and responds by proposing that individuals arrive at university with different levels and types of capital. In drawing upon the tenets of critical race theory, community cultural wealth is positioned within a strengths perspective that does not equate "disadvantage" as being without "normative cultural knowledge and skills" (p. 75). For Yosso, this deficit perspective simply fails to recognise what the student or the family brings with them to the educational environment and instead expects adaptation and conformity on the part of the individual in order to exhibit the accepted cultural capital. This framework incorporates six defined forms of capital, including "aspirational, navigational, social, linguistic, familial and resistant" (p. 77). This was later extended by Huber (2009) to include spiritual capital that references connection to "a reality greater than oneself" (p. 721).

Rather than viewing these students as lacking, this theoretical framework innovatively recognises the strengths and cultural wealth of diverse communities. This is not to say that the individuals in this study did not express a lack of understanding of the capital expected and valued within this institution, but rather as the later quotes will highlight, each arrived at university in possession of extensive capital reserves which they drew upon in order to move through and succeed within the higher education environment. 


\section{RESEARCH LOCATION AND PARTICIPANTS}

This research study took place at a small regional campus (3,500 students) of a larger institution, currently ranked 11th nationally for research and teaching out of the 39 publically funded universities in Australia. The campus is located in a region that is recognised as being economically and socially disadvantaged, indicated by educational attainment and employment rates. According to the Australian Bureau of Statistics (2006) and the latest labour force profile for this region (2008) just under half (48.1\%) of the regional population leave school with no formal qualifications; of those who do continue with education, only $31.0 \%$ complete high school (compared to $49.0 \%$ for the nearest metropolitan area) and $9.4 \%$ of residents hold a bachelor's degree, compared to $14.6 \%$ for the nearest metropolitan area and 16.4\% for the state. At the time of this study, more than half of the campus population was categorised as mature-aged (over the age of 21) and many had used alternative forms of entry to university: this included the university's access program, which provided a university admissions ranking for entry upon completion. A limited number of degree programs in the arts, health, sciences, and education fields were offered at this campus, which could be termed a "commuter campus" as students largely attended lectures and then left campus. The campus had only one small on-campus student residence housing approximately 25 students. Many of the lecturers commuted between the various campus locations to deliver lectures, and this situation arguably added to the disjointed and deserted nature of the campus environment. Having said that, the small size of the campus also facilitated a level of familiarity between staff and students that is often not possible at larger institutions. The women in this study frequently commented upon this friendliness, indicating how they knew on-campus library staff, retail staff, and student support staff by name.

Invitations to participate in the study were distributed at the university commencement ceremony held to mark the beginning of each student's academic career: all first-year undergraduates are invited, and the ceremony includes an academic procession led by the Vice Chancellor or President of the university. An announcement about the research was made at the end of the official proceedings, just prior to the scheduled orientation activities. In addition, flyers detailing the study and asking for volunteers were placed on each of the seats in the hall. The study was purposive in the sense that each participant was female and identified as being first in family to attend university. For the purposes of this study, this status was defined as no one in the immediate family having attended university previously, including spouses or partners, children, parents, and immediate siblings. A purposive sample of 17 female students was recruited to participate in the study (1 student dropped out of university after the first interview). The Table 1 summarises the demographic nuances of this particular group:

While the study used gender and first in family as the criteria for the sample interviewed, many of the women interviewed were also parents, both married and single. Three of the women disclosed mental health issues, and others described severe economic stress in the household. Ten of the participants had children and three of these were sole parents. The youngest participant was 18 years old and the eldest was 44 at the time of the interviews, which occurred between 2006 and 2007. None of the participants had been enrolled at university before and each had entered via a diversity of measures. Only two of the participants had wholly used 
TABLE 1.

Details of Participants $(N=17)$

\begin{tabular}{|c|c|c|c|c|c|c|c|}
\hline Pseudonym & Age & Status & Children \& Ages & Entry & Study & $\begin{array}{l}\text { High School } \\
\text { Grad }\end{array}$ & Prior to University \\
\hline Annie & 18 & Single & None & $\mathrm{HSC}$ & Early Childhood & Yes & School \\
\hline Catherine & 44 & Single & One (15) & STAT & Nursing & Yes & P/T Masseuse \\
\hline Clara & 23 & Single & One (5) & $A C$ & Early Childhood & No & Child Care Asst. \\
\hline Heidi & 47 & Divorced & Three $(20+)$ & TAFE & Social Science & No & Nurse (retired) \\
\hline Helen & 22 & Partnered & None & TAFE & Business & No & Trainee (Office) \\
\hline Jane & 32 & Married & Three $(2,4,8)$ & $A C$ & High School (Ed) & Yes & $\begin{array}{l}\text { Housewife/Home } \\
\text { business }\end{array}$ \\
\hline Katie & 33 & Married & Two $(6,9)$ & STAT & Oral Health & Yes & Dental Asst. \\
\hline Kira & 38 & Separated & $\begin{array}{c}\text { Five }(6,8,14,15 \\
18)\end{array}$ & TAFE & Psychology & No & Youth Worker \\
\hline Linda & 32 & Single & Two $(9,10)$ & $A C$ & Education & No & Volunteer \\
\hline Mary & 18 & Single & None & HSC & Education & Yes & School \\
\hline Nicki & 33 & Single & One (2) & HSC TAFE & Education & Yes & Retail \\
\hline Rachel & 22 & Single & None & TAFE & Social Science & Yes & P/T Retail \\
\hline Sheila & 31 & Married & Two $(5,7)$ & STAT & Education & Yes & P/T Hospitality \\
\hline Stephanie & 34 & Married & Four $(8,9,3,18)$ & & Access Course & No & P/T Retail \\
\hline Sue & 39 & Married & Two $(8,10)$ & STAT & Education & No & Volunteer \\
\hline Susie & 38 & Married & Two $(3,6)$ & $A C$ & Social Science & No & Bar attendant \\
\hline Vicky & 45 & Married & Three $(16,19,22)$ & $A C$ & Nursing & Yes & Caregiver \\
\hline
\end{tabular}

Notes. $\mathrm{HSC}=$ high school certificate, STAT = State Tertiary Admission Test, TAFE = Technical and Further Education Colleges, $\mathrm{AC}=$ access course.

their high school qualifications as the basis for entry, the majority $(n=10)$ had entered on the basis of prior qualifications either via the access program offered at the university or through recognition of prior qualifications obtained in technical colleges. The remaining four students undertook a state examination, which again provided the requisite ranking for university applications.

\section{METHOD}

This is a qualitative study that draws upon the interpretivist tradition and is methodologically situated within a narrative inquiry framework. Denzin (1997) differentiates between various narrative texts, identifying the characteristics of a "life history," a "self story," and a "personal experience narrative." I focused on the latter as the participants addressed questions pertaining to both their reasons for coming to university and their personal experiences related to becoming a student. The repeated interactions with participants enabled the research conversation to explore the past and present, these stories spanned the life course with participants frequently returning to themes and events throughout the research process. Narrative is ideally positioned to explore the situatedness of human action and present a more embodied version of the lived experience. This study draws upon an "analysis of narrative," which 
involves a "recursive movement" between the interview data and the codes or categories that emerged inductively based on commonalities found within individual narratives (Polkinghorne, 1995, p. 10).

Telling stories is one method of taking control of life and reclaiming ownership of actions; however it can also be argued that the act of interpretation may reduce this power, suggesting that individuals are simply buffeted by the winds of cultural constraint (Ochberg, 1996). To circumvent this possibility, the researcher needs to not only identify the dominant discourses at play within the narrative but also maintain a sense of "wakefulness" in order to avoid simplistic or descriptive analyses. By continually returning to the data with different conceptual lenses the interview data is not perceived as indicating one absolute truth, but rather as distinct pieces in an evolving puzzle (Clandinin \& Connelly, 2000).

Interview data were examined in a multivariegated way, beginning with the naming and categorisation of the conversations; the resulting fragmentation of data led to the creation of thematic codes and from these analytic concepts and interpretative frameworks were derived. By drawing on Peirce's (19311960) "abductive reasoning" I initially strived to identify specific phenomenon in my analysis, but then in order to open this up, various conceptual frameworks were applied. A range of events or aspect of the research were interpretatively defined and also engaged with imaginatively, as Charmaz (2006) identifies, framing data in relation to different conceptual frames can assist in breaking through the "ordinariness of routine events" (p. 53).

This process was assisted by the frequency of interviews, which were conducted at four discrete points over one academic year. I also conducted and transcribed all the interviews $(n=65)$ enabling me to maintain closeness to the data. The meetings coincided with the beginning and end of each semester; the ongoing nature of these meetings also provided the means to peer debrief as I sought clarification and further detail from interviewees while checking previous interview content. Conducting regular and substantive interviews is particularly important when interviewing women, as it provides entry into the private realms of life and allows female participants the opportunity to explain issues in their own terms and in their own time (Smith, 1996).

Undoubtedly, my positionality impacted upon the analysis of this data with my professional role on campus increasing the complexity of this situation. Concurrent to this research, I was also coordinating the provision of academic skills support to all students at the campus. This position meant that I was sometimes placed in the role of what Cotterill and Letherby (1994) define as the expert, from whom participants would seek advice about academic issues. In dealing with this dual position, it was necessary to demarcate between my role as researcher and my campus role by stating to students that I would avoid referencing the research while engaged in support work with them and that equally I would not endeavour to provide academic assistance while interviewing. Frequently, once the tape recorder was switched off, I would offer suggestions relating to academic support particularly if students were expressing frustration in terms of managing time or completing assignments, as it was my professional responsibility to address issues of concern for students. I occasionally also saw students outside of interviews while I was teaching or in individual appointments, which might be perceived as further complicating my positioning and also underlining a power differential. Equally this ongoing contact could also be perceived as enriching the interview 
relationship and increasing the level of rapport. Interview questions covered a diversity of topics, exploring areas such the reasons for the return to education at this point in life; initial perceptions of the university environment, highs and lows through the academic year, and impacts upon family and community.

\section{RESULTS AND ANALYSIS}

When students enter the university environment, many are placed at a disadvantage, particularly if the environment is one that they have had little or no contact with beforehand (Crozier, Reay, Clayton, Colliander, \& Grinstead, 2008; Reay, Davies, David, \& Ball, 2001). For first-in-family students, the very act of arriving at university may be perceived as a radical departure for those closest to these individuals. Friends and family members may have little understanding of what the students are undertaking and may not be able to provide advice or support. The capital expected within the higher education institution may not only be alien to these students but perhaps be regarded as somewhat threatening by others. The participants narrated various reactions to their decision to attend; some like Susie received mixed responses from family members:

\begin{abstract}
My sister-in-law belted the crap out of me one night from behind cos she thought it was a waste of time and a big toughie who has just got out of jail.... She was very, very jealous of the fact that I was going to uni.... So she did not like it and going: "Why are you doin' that? You're too old to be doing it, too stupid to be doing it." And things like that, but I just let it pass. ... But my nieces are awesome about it, my older sister's two girls ... they're going: "Ahh cool, Aunty Susie."
\end{abstract}

Susie's attendance at university seemed to have been perceived as a disruption to the expected life course, but while her sister-in-law was violently opposed to this alternative route, her younger nieces welcomed her choice. Susie's quote also indicates how not only are the voices of the participants present in these accounts, but also those belonging to others. The following sections focus on the voices of both the students and also significant others under the themes arriving, surviving, and succeeding; these sections reflect the temporal nature of the interview process and are used to contextualise the various narrative themes that emerged as the year progressed.

\section{Arriving}

I think it comes down to just everyone assuming that you know what to do, but nobody really speaking up and saying: "Well, I don't know what to do." (Jane)

At the initial interview all the participants $(N=17)$ narrated a notable lack of not only cultural capital but also basic knowledge capital relating to the institution. The following quotes indicate how these participants felt bewildered by even the most fundamental institutional processes, for example, enrolment procedures, financial requirements, timetabling. Overall, there seemed to be an assumption of knowledge capital on the part of the institution, a situation that clearly needs to be addressed.

You just have no [emphasis] idea and there is nowhere to get any idea. (Clara)

Probably that first day ... stands out most. That was probably the most stress that I remember feeling cos it was completely unfamiliar territory. I didn't know where to go, didn't know who to ask, didn't know what to do. (Catherine)

Catherine continued by describing how initially she felt quite lonely when she started, a perspective echoed by other participants. Frequently, these sentiments were related to the distance they felt in relation to other students and actual academic practices. 
You feel so alone sometimes. It's just so many people, like hundreds of people, everywhere, and you don't know any of them. Like it's a bit daunting and stuff. (Mary)

For six of the participants in this study, the nature of relationships with lecturers also deviated strongly from their expectations and their needs. Kira expected lecturers to be "more approachable and helpful": instead, "They don't answer questions in their lectures, so you can walk away . . . knowing absolutely nothing." While some of the participants blamed others for their lack of knowledge, equally some looked to themselves as being an outsider or "imposter" lacking legitimacy within this environment. Katie highlighted just such a perception when she narrated a visit to a course coordinator to request a transfer to another course:

It's daunting . . . like this is [someone] who has a $\mathrm{PhD}$ and she is a university coordinator. Like she developed and made up the whole course, and then [for me] to go up and knock on her door and go, "I am too stupid to have got into this course, but can you now let me in?" (Katie)

Arriving at university with little understanding of how systems work, navigating an expectation-reality mismatch, and also working out how to move through the academic environment provide specific challenges for those students who are stigmatised as nontraditional. While the initial weeks of university are difficult for most students, for those who have had limited exposure to the workings of higher education institutions and who have no one within their family or social networks to seek advice from, often relatively small issues can be exaggerated. Vicky, an older married student, identified how not having an "insider" available to discuss the expectations of the environment was one of the major obstacles to her initial transition to this environment:

I don't know, maybe what I needed more than anything else was to be able to tell somebody that I was totally overwhelmed and I didn't feel like I was coping and ... I mean obviously I know that there's counseling and things like that provided, but I just didn't feel that it was significant enough to have an appointment with the counselor.

However, in order to overcome this initial sense of disjuncture, over time the participants demonstrated a diversity of strategies designed to negotiate a "sense of fit." For the older participants, it was the number of other mature-aged students present on campus that reassured them about their choice. For example, Sue explained how focussed she was on the age of other students on her first day of lectures, recalling how she was "watching people ... thinking: 'Oh good, she's older, she's older.' [laughs] I think I must have been pretty preoccupied with age." Similarly, Vicky described how her initial thoughts focused on: "Ohmigod! I don't want to be the oldest person at university." seeing other mature-aged students increased her confidence and made for a more comforting initiation into this environment. There seemed to be a general misapprehension among the participants that the university student population would be predominantly youthful. For example, Annie's perception of university was largely based upon popular culture: "just from watching the movies ... like a lot of American TV and stuff like that." Similarly, Sue highlighted how she perceived university to be "a big party, and kids go out and drink and, you know, all sorts of stuff." However, the contemporary student demographic is a diverse one, but this diversity, particularly as it relates to age, is often neglected or sidelined in university publications. 


\section{Surviving}

I've just gotta pass first and ... I've just gotta try and get through it. (Nicki)

In the initial two interviews, survival or surviving was referenced in relation to material or financial circumstances, particularly for the single parents, and also in terms of participants' relationships with the university. In terms of the latter, survival was defined as "getting through." For some this first year was perceived as a trial or as a period where personal capability could be measured. Both Mary and Kira described how they intended to initially "aim for a pass" and then apply themselves more, later in the degree.

This first year I thought I'd just aim for pass or get credits. . . . If I pass my subjects this semester, I think I will apply myself a lot more next semester and during next year. (Mary)

The reference to survival was in some cases related to circumstances, as for Kira who had been married with five children, later separating from her husband within months of commencing her degree. During the second interview, she explained that one of the reasons for the demise of the relationship was her decision to enrol at university:

I think study opened my eyes up a lot more. When I wanted answers and he didn't, he was just happy to let it be and I wasn't, so I think study contributes [umm] but it's not the be all and end all reason.

For Kira, survival was translated as simply completing the year, and she actively put strategies in place to make this possible, including reducing her study load, recognising her own desire and self-determination to complete, as well as seeking out help and support from others: "It is my own determination not to give up. ... When the going got tough and I just thought, 'No, I'll stick it out,' and I am glad I did. I had some of the classmates pull me through the last semester." Kira was not the only participant to talk about this first year in terms of survival; seven of the participants made references to getting through or just passing. Like Jane who admitted that she was "just doing the bare minimum to get through." Susie explained how she was "just aiming to pass, aim to pass"; similarly, Rachel wanted to "get through the semester and pass." The articulation of this "getting through" mentality may reflect an insecure space that the participants occupied within the university landscape. If individuals feel that they do not belong in this environment or have existing "fragile" learning identities, then to imagine a future successful student self may be difficult or may not fit with current identity. A number of these participants had been absent from education for 10 or even 15 years, and so could be regarded as moving from an identity based upon a lack of education to one with a university education: this is a dramatic reconceptualisation, particularly for those who may have had previous negative educational experiences. This insecurity was further highlighted by an initial reluctance to identify as a student; for example Vicky stated: "I don't think I'm ready to bravely say I'm a university student"; and other parents, like Stephanie who regarded herself as "Mum first."

When revisiting the participants at the end of the first semester, all but 1 had managed to continue with or "survive" their studies. Unfortunately, Vicky departed the university and did not respond to further contact so the reasons for departure remain ambiguous. The remaining 16 participants talked about some of the obstacles that they had encountered but also, revealed transformations in confidence levels and defined a greater sense of personal control; this was a universal manifestation. Each of the participants reflected upon similar developments, only the degree and the 
repercussions of this change differed.

The growth in confidence led to 5 of the participants highlighting how they felt "more comfortable" within the university environment. This might simply be a better awareness of such things as room locations or how to utilise the library; but such transformations made a qualitative difference to student experience. These increases in confidence levels also extended outside of the institution. By the third interview, Katie described how she "felt smarter" and as a result she is "better talking to people" in general. When further explaining this transformation, she juxtaposed between her previous tentativeness to a more confident, assertive Katie:

Whereas before I'd say: "Oh yeah, that doesn't sound right" or "That sounds too much," now I can confidently say: "Oh no, ... that's not the way it happens: it happens this way." I feel confident that I can talk to people that way.

Such reflections were not demarcated by age or status, but for some of the married women these new levels of confidence affected the dynamics of relationships with partners. In Susie's case, the knowledge acquired in university has resulted in a more assertive opinion on things:

Some of the remarks that I have been spitting back at my husband when he's been saying things have just stopped him dead in his tracks.... I come out with these things that he knows about and I've never known about [before].

Equally, Stephanie explained how university has initiated confidence "in my own ability to do things," like assuming responsibility for tasks that previously she felt were beyond her abilities, such as completing household paperwork: "I used to always say to my husband, 'Here, you fill it out and I'll sign it.' Now I . . . fill it out myself and don't have any worries." The statements reflect the very tangible repercussions that university was having on participants' lives: there is a clear sense of a "then" and a "now." For these students, coming to university was an emotional experience that cannot be measured solely in terms of vocational or knowledge outcomes, but also involved public and private transformations. The changes engendered by this decision also led to shifts in marital relationships. By choosing to persist at university, the mature-aged married women in this study chose to reclaim some ownership of their lives and extended the boundaries of domestic space; this shift sometimes necessitated radical renegotiations in relationships with family members.

If [my husband] doesn't want to support me for the next 5 years, then if he wants to leave, leave. But I am not going to stop him from doing it. This is what I want to do. (Stephanie).

While the demands of university could be divisive, the act of returning was also regarded as a catalyst for positive change in relationships with children. Four of the mothers reflected upon such positive repercussions. By the third interview, Kira and Linda recognised the benefits that university attendance had brought to their mother-child relationships. In Kira's case, she hoped that her "going to uni encourages [my daughter] to think, 'Well I could do it," as opposed to how she felt at that age (14 years old), thinking "I didn't have the brains" to go to university. Clara, a single parent, also reflected on how this decision to come to university fundamentally altered the positioning of higher education in her child's future:

I am the first person in my family to go to university and that hopefully my daughter will go to university as well and that I have cracked the cycle. 
In "cracking the cycle," Clara placed university within the discourse of a future "good life" and a means to get out of a "poverty trap" as well as highlighting how her own attendance gave university a "place in her family life." Catherine and Heidi, both single parents, reflected how their sons now think, "Okay, Mum's got a brain in her head" (Catherine); as Heidi further elaborated: "My eldest son said, 'God, I never would have thought that you'd be smarter than me.' 'This attendance also demonstrated to their children that university was a possibility rather than something other people did.

It has definitely spurred them on. . . He did his [High School Certificate], didn't do real well, you know. Got it and had no desire to go to Uni ... and he said to me, "You know, I think I'm gonna go next year." So it has definitely, you know, spurred him on. He'll be 26 this year. (Heidi)

Heidi's experience is echoed by some of the younger mothers as well, who described how their children discussed how "Mum is going to uni," clearly now locating university within family discourses. By participating in university, these women have introduced a new worldview into the family dynamic. They are also better positioned to prepare their children for the institutional habitus or the internalised, taken-for-granted rules associated with this educational institution.

\section{Succeeding}

I have done this, you know, despite all the hiccups. ... I got through. (Catherine)

The final interview at the end of the year provided participants with an opportunity to revisit future hopes and ambitions. Seven of the participants described their future in more dynamic ways. In Annie's case she was "looking at making my options a bit broader," while Heidi and Katie were considering careers within the university, indicating a reluctance to leave an environment where they "felt so complete." In the third interview, Katie declared, "I love being here"; and by the end of the year saw her future career objective as "being here teaching this course." Kira described the shift in her own thinking that, while welcomed on a personal level, did contribute to the demise of her marriage:

Going off to uni I want answers. I want to know why things happen. I want to know why this person feels that way. I want answers. I want to know why and unfortunately [my husband didn't], and therefore we are sailing in different directions. (Kira)

Ten of the participants also defined how the interviews provided a space for a collective voice; in other words this process facilitated a means to negotiate the university experience as a group. While the interviews were conducted individually, all of the participants were aware that the study involved a number of women. This realisation made the women aware that there were others just like them, almost a collective identity.

Obviously you see other people to me who have very similar stories. I am no different to anyone else out there and ... we are able to voice our opinion and say: "Yeah, this is why we are here. This is how important it is." (Heidi)

The interview process also offered an opportunity to reflect upon the university experience, reflection that may not have been possible outside of the campus environment. Heidi explained how the interviews "made me actually reflect a bit more on exactly what the process was I was going through and what was good, sometimes when all I was thinking about was what was bad." Similarly, Helen described: "It has been good for me to be able 
to say, just to express that I have had a bad time here and a good time here and talk to someone who understands rather than trying to talk to my boyfriend or something." Sheila explained how the research experience has been validating simply because participating "makes you think, well, someone is interested in knowing, someone wants to know." Similarly, Clara highlighted the importance of being able to hear "what other people are going through and learning from it." The following section explores these areas in more depth, relating the experiences of this cohort of female students to the wider literature on first-in-family students and transition to university.

\section{DISCUSSION}

The article has presented a snapshot of one cohort's experiences of moving through an academic year at a small campus. This representation is not designed to be a window on all of reality, but rather presents a unique perspective at a particular point in time. Despite the "opaque" or "murky" nature of such narratives (McLeod \& Thomson, 2009), the themes that have emerged undoubtedly resonate with the experience of students in other HE institutions. The narratives also indicate how a number of tensions exist within the university environment, including the expectations of students compared to the realities of the environment, as well as the differing types of cultural capital that students arrive with. These insights highlight how these participants did not necessarily lack cultural capital, but the difficulty was that it was in a different currency (Reay et al., 2001, p. 870). Given policy moves to increase access to higher education, it is vital that these students are not stigmatised as lacking overall. A cursory examination of the literature and research in this field reveals how first-in-family students are often framed as deficient: terms such as "challenges," "difficulties," and "help" are replete in the literature (Thayer, 2000; Brachman, 2012; Gardner, 1996), which has a tendency to problematise those who are first in family and "lack the necessary cultural capital” (Mehta et al., 2011, p. 22). These types of perspective place the responsibility for this lack upon the individuals and their families, while educational institutions are charged with the task of "filling up" students with "forms of cultural knowledge deemed valuable by dominant society" (Yosso, 2005, p. 75). The individual students are those who have to change in order to create fit between their existing knowledge and that valued within the higher education system.

This is not to say that first-in-family students do not express gaps in knowledge, as clearly summed up by the participants themselves in this study when they reflected upon their first year:

There is no one here to guide you. I think that is the biggest thing: you don't know what you are doing right. (Kira)

Despite struggling at the beginning, the women were determinedly persistent to succeed and seemed rich in what Yosso (2005) terms as aspirational capital, demonstrated by their ability to persist despite little understanding of university practices. Instead, the women allowed themselves to "dream of possibilities beyond their present circumstances often without the objective means to attain these goals" (Yosso, 2005, p. 78). This aspiration for education can be regarded as a form of cultural wealth, acting as a catalyst not only for the individual students, but also their families and community.

The literature also points to a struggle between maintaining connections with family and community while simultaneously engaging in the higher education environment (Stieha, 2010; Edwards, 1993), one may be 
perceived as being incompatible with the other; however Gouthro (2005) argues that this incompatibility can be reframed, suggesting a need for recognition that the public space of the learning and the private space of learning (i.e., the home and family) can inform and support each other. Similarly, Yosso (2005) refers to the importance of recognising "familial capital" as a source of strength and knowledge. This is echoed by Huber (2009) in her study of 10 Chicana undergraduate students who drew upon familial capital as both inspiration and motivation to continue education. For the participants in my research, while not all members of the family could be counted upon for support, a number of the women did refer to extended family as motivators and helpers who assisted them to succeed and continue. Annie explained how her extended family and community provided a source of motivation and reassurance:

\section{My grandparents think it's wonderful. They tell everyone. And my aunty ... just everyone, even family and all Mum's friends, I don't really know them but they always ask: "How are you doing?" So it's been pretty good. I don't think I'll ever struggle, like, I'll never [not] know what to do, cos I'll have people to turn to. (Annie)}

This type of familial capital limits isolation and instead provides an alternative support network that first-in-family students can draw upon; but this may not always be valued or recognised within the higher education environment.

A somewhat unexpected but important form of support identified in the participants' stories was the opportunity to reflect upon this university experience. The interpretative and sense-making nature of these interactions was referred to at length by this cohort. For Linda, the interviews had "made me think a bit deeper about how I view things"; whereas Nicki revealed how the meetings helped clarify issues and allowed her to "go away and deal with [them]." Storying these autobiographical accounts provided participants an opportunity to justify and explain their departure from expected and established patterns of behaviour. Arguably, the interviews provided the means for the participants to acquire "social capital" (Yosso, 2005), with meetings providing the means to both reflect upon this experience and seek advice from an experienced peer. Encouraging participants to reflect upon and articulate the changes being experienced assisted them to understand the evolving nature of this transition to university.

\section{FINAL CONCLUSIONS AND RECOMMENDATIONS}

The process of arriving, surviving, and succeeding for these students was characterised by personal growth and change. Such personal transformations should be acknowledged and celebrated as the stories of women who have succeeded in this environment may encourage others to enter. Foregrounding such stories of success within the adult education field is a key recommendation derived from this study. For the students in this study, it was this personal growth that emerged as one of the consistent gains from participating in university study. All the participants referred to increases in confidence and self-efficacy, but this was particularly noted in relation to the older women, many of whom were parents. The changes in relationships with children noted by the mothers in this study not only reflected a new status in the household but also opened up the possibility of university studies for the children themselves. Returning to education enabled the women to build "navigational capital" (Yosso, 2005) which had the potential to assist other family members to move successfully through this environment.

Traditionally, engagement in higher 
education has been perceived in a very physical sense (Vaccaro \& Lovell, 2010), but this research has highlighted how engagement can also be conceived as more psychical in nature. This is particularly obvious when the women refer to university as providing a space for reflection; this is not necessarily a physical space but instead was conceived in a more embodied sense. The participants in this study were provided with a means to "move forward." Articulating and reflecting upon this movement into the higher education environment provided the means to both make sense of this journey, and also extend their repertoire of biographical knowledge. This research did not give this group a voice; all these women came to the research with strong voices, but with no listeners. This suggests that many students, particularly those from backgrounds where attending university is not the norm, may need a "critical friend" within the university landscape who can listen and advise on an ongoing basis. Such a role should be negotiated as "everyone's business" and built into both professional and academic staffing profiles, much like the coaching and mentor arrangements within business. Further, the learning potential of such interactions should not be overlooked. The act of narrating stories can be regarded as a learning process for individuals, offering the opportunity for reflection on the nature of agency.

The challenge of accommodating the needs of heterogeneous student populations undoubtedly engenders a need for continuing research that addresses the issues that impact upon student retention and attrition. The challenge for educational researchers is to recognise the strengths and knowledge that all students arrive with at university. This means moving beyond a deficit discourse that frames students as somehow lacking and instead examining this environment with an alternative lens: Yosso's (2005) community cultural wealth framework is one such lens. For those of us who work in the support roles or are involved in teaching students, there is a responsibility to not only acknowledge these strengths, but also to foreground them in how we define and assist student cohorts. This then is the challenge as student populations increase in number and diversity: working within a strengths perspective enables us all to not only recognise but also value the cultural worth of first-in-family students.

Correspondence concerning this article should be addressed to Sarah O’Shea, saraho@uow.edu.au 


\section{REFERENCES}

Aschaffenburg, K., \& Mass, I. (1997). Cultural and educational careers: The dynamics of social reproduction. American Sociological Review, 62, 573-587.

Australian Bureau of Statistics. (2006). Australian Bureau of Statistics census data. Retrieved from http://australia.gov.au/topics /australian-facts-and-figures

Australian Bureau of Statistics. (2009). Survey of training and education. Retrieved from http://www.abs.gov.au/AUSSTATS

Bloomer, M., \& Hodkinson, P. (2000). Learning careers: Continuity and change in young people's dispositions to learning. British Educational Research Journal, 26, 583-597.

Bourdieu, P. (1977). Outline of a theory of practice (R. Nice, Trans.). Cambridge, England: Cambridge University Press.

Bourdieu, P., \& Passeron, J. C. (1977). Reproduction in education, society and culture. London, England: SAGE.

Brachman, C. (2012). Improving access and success for firstgeneration college students. America's Promise Alliance. Retrieved from http://www.americaspromise.org/news /improving-access-and-success-first-generation-college-students

Bradley, D., Noonan, P., Nugent, H., \& Scales, B. (2008). Review of Australian higher education: Final report. Retrieved from http://www.deewr.gov.au/HigherEducation/Review

Charmaz, K. (2006). Constructing grounded theory: A practical guide through qualitative analysis. London, England: SAGE.

Chen, X. (2005). First-generation students in postsecondary education: A look at their college transcripts (NCES 2005-171). Washington, DC: National Center for Education Statistics, U. S. Deparment of Education.

Clandinin, D. W., \& Connelly, M. F. (2000). Narrative inquiry: Experience and story in qualitative research. San Francisco, CA: Jossey-Bass.

Coates, H., \& Ransom, L. (2011, June) Dropout DNA, and the genetics of effective support. Australasian Survey of Student Engagement Research Briefings, 11, 1-16. Retrieved from http://research.acer.edu.au/ausse/1

Cotterill, P., \& Letherby, G. (1994). The "person" in the researcher. Studies in Qualitative Methodology, 4, 107-136.

Couvillion-Landry, C. (2002-2003). Retention of women and people of color: Unique challenges and institutional responses. Journal of College Student Retention, 4, 1-13.

Crozier, G., Reay, D., Clayton, J., Colliander, L., \& Grinstead, J. (2008). Different strokes for different folks: Diverse students in diverse institutions-Experiences of higher education. Research Papers in Education, 23, 167-177.

Denzin, N. K. (1997). Biographical research methods. In L. J. Saha (Ed.), International encyclopedia of the sociology of education. Canberra, Australia: Pergamon.

Edwards, R. (1993). Mature women students: Separating or connecting family and education. London, England: Taylor \& Francis.

Evans, S. (2009). In a different place: Working-class girls and higher education. Sociology, 43, 340-355.

Forsyth, A., \& Furlong, A. (2003). Access to higher education and disadvantaged young people. British Educational Research Journal, 29, 205-225.

Gardner, J. N. (1996). Helping America’s first-generation college students. About Campus, 1, 31-32.
Gorard, S., Smith, E., May, H., Thomas, L., Adnett, N., \& Slack, K. (2006). Review of widening participation research: Addressing the barriers to participation in higher education (Report to HEFCE by the University of York, Higher Education Academy and Institute for Access Studies). Bristol, England: Higher Education Funding Council for England.

Gouthro, P. (2005). A critical feminist analysis of the homeplace as learning site: Expanding the discourse of lifelong learning to consider adult women learners. International Journal of Lifelong Education, 24, 5-19.

Harrell, P. E., \& Forney, W. S. (2003). Ready or not, here we come: Retaining Hispanic and first-generation students in postsecondary education. Community College Journal of Research and Practice, 27, 147-156.

Higher Education Funding Council for England. (2010). Trends in young participation in higher education: Core results for England. Issues Paper. Retrieved from http://www.hefce.ac .uk/data/Year/2010/Trends,in,young,participation,in, higher, education,core,results, for,England/Title,93032,en.html

Higher Education and Statistics Agency. (2012). Higher education student enrolments and qualifications obtained at higher education institutions in the UK for the academic year 2010/11. Retrieved from http://www.hesa.ac.uk/sfr169

Hillman, K. (2005). The first year experience: The transition from secondary school to university and TAFE in Australia (Longitudinal Surveys of Australian Youth Research Report, No. 40). Camberwell, Victoria: Australian Council for Educational Research.

Huber, L. (2009). Challenging racist nativist framing: Acknowledging the community cultural wealth of undocumented Chicana college students to reframe the immigration debate. Harvard Educational Review, 79, 704-784.

James, R. (2008). Participation and equity: A review of the participation in higher education of people from low SES backgrounds and Indigenous people. Melbourne, Australia: Centre for the Study of Higher Education.

Kantanis, T. (2000). The role of social transition in students': adjustment to the first-year of university. Journal of Institutional Research, 9(1), 100-110.

Lehmann, W. (2009). University as vocational education: Working class students' expectations for university. British Journal of Sociology of Education, 30, 137-149.

McLeod, J., \& Thomson, R. (2009). Researching social change: Qualitative approaches. London, England: SAGE.

Mehta, S., Newbold, J., \& O'Rourke, M. (2011). Why do firstgeneration students fail? College Student Journal, 45, 20-34.

National Centre for Educational Statistics. (2012). Digest of education statistics, 2011 (NCES 2012-001). Washington, DC: U.S. Government Printing Office.

Ochberg, R. L. (1996). Interpreting life stories. In R. Jossellson (Ed.), Ethics and process in the study of lives. Thousand Oaks, CA: SAGE.

Oldfield, K. (2012). Still humble and hopeful: Two more recommendations on welcoming first-generation poor and working class students to college. About Campus, 17(5), 2-13.

Pascarella, E., Pierson, C., Wolniak, G., \& Terenzini, P. (2004). First-generation college students: Additional evidence on college experiences and outcomes. Journal of Higher Education, 75, 249-284. 
Peirce, C. S. (1931-1960). Collected Papers of Charles Sanders Peirce (Vols. 1-6, C. Hartshorne \& P. Weiss, Eds.; Vols. 7-8, A. W. Burks, Ed.). Cambridge, MA: Harvard University Press.

Polkinghorne, D. E. (1995). Narrative configuration in qualitative analysis. International Journal of Qualitative Studies in Education, 8, 5-23.

Quinn, J. (2005). Belonging in a learning community: The re-imagined university and imagined social capital. Studies in the Education of Adults, 37, 4-17.

Reay, D. (1998). Surviving in dangerous places: Working-class women, women's studies and higher education. Women's Studies International Forum, 21, 11-19.

Reay, D., Crozier, G., \& Clayton, J. (2009). "Fitting in" or "standing out": Working class students in UK higher education. British Educational Research Journal, 36, 107-124.

Reay, D., Davies, J., David, M., \& Ball, S. (2001). Choices of degree or degrees of choice? Class, "race" and the higher education choice process. Sociology, 35, 855-874.

Rendon, L. (1992). From the barrio to the academy: Revelations of a Mexican American "scholarship girl." New Directions for Community Colleges, 80, 55-64.

Rendon, L. (1995). Facilitating retention and transfer for firstgeneration students in community colleges. Paper presented at the The New Mexico Institute, Rural Community College Initiative, Española, NM.

Schuetze, H. G., \& Slowey, M. (2002). Participation and exclusion: A comparative analysis of non-traditional students and lifelong learners in higher education. Higher Education, 44, 309-327.
Smith, S. (1996), Uncovering key aspects of experience: The use of in-depth interviews in a study of women returners to education. In E. Stina Lyon \& J. Busfield (Eds), Methodological imaginations. London, England: Macmillan.

Stieha, V. (2010). Expectations and experiences: The voice of a first-generation first-year college student and the question of student persistence. International Journal of Qualitative Studies in Education, 23, 237-249.

Thayer, P. B. (2000, May). Retention of students from first-generation and low income backgrounds. Opportunity Outlook, 2-8.

Vaccaro, A., \& Lovell, C. (2010). Inspiration from home: Understanding family as key to adult women's selfinvestment. Adult Education Quarterly, 60, 161-176.

Wakeling, P., \& Kyriacou, C. (2010). Widening participation from undergraduate to postgraduate research degrees: A research synthesis. York, England: Economic and Social Research Council.

Walkerdine, V., Lucey, H., \& Melody, J. (2001). Growing up girl: Psychosocial explorations of gender and class. Hampshire, England: Palgrave.

West, L. (1996). Beyond fragments: Adults, motivation, and higher education: A biographical analysis. London, England: Taylor and Francis.

Wyatt, J., \& Mattern, K. (2011). Low-SES students and college outcomes: The role of $A P^{\star}$ [Advanced Placement Program] fee reductions (Research Report 2011-9). New York, NY: College Board.

Yosso, T. (2005). Whose culture has capital? A Critical Race Theory discussion of community cultural wealth. Race, Ethnicity and Education, 8, 69-91. 